\title{
Rabies transmitted by vampire bats to humans: An emerging zoonotic disease in Latin America?
}

\author{
Maria Cristina Schneider, ${ }^{1}$ Phyllis Catharina Romijn, ${ }^{2}$ Wilson Uieda, ${ }^{3}$ \\ Hugo Tamayo, ${ }^{4}$ Daniela Fernandes da Silva, ${ }^{5}$ Albino Belotto, ${ }^{6}$ \\ Jarbas Barbosa da Silva, ${ }^{5}$ and Luis Fernando Leanes ${ }^{6}$
}

Suggested citation

Schneider MC, Romijn PC, Uieda W, Tamayo H, da Silva DF, Belotto A, da Silva JB, Leanes LF. Rabies transmitted by vampire bats to humans: An emerging zoonotic disease in Latin America? Rev Panam Salud Publica. 2009;25(3):260-9.

\begin{abstract}
Human rabies transmitted by vampire bats reached new heights in Latin America in 2005. A total of 55 human cases were reported in several outbreaks, 41 of them in the Amazon region of Brazil. Peru and Brazil had the highest number of reported cases from 1975 to 2006. In Peru, outbreaks involving more than 20 cases of bat-transmitted human rabies were reported during the 1980s and 1990s. During this period, a smaller number of cases were reported from outbreaks in Brazil. A comparison of data from field studies conducted in Brazil in 2005 with those from the previous decade suggests similar bat-bite situations at the local level. The objective of this study was to review the epidemiological situation and, on the basis of this information, discuss possible factors associated with the outbreaks. Prevention and control measures already recommended for dealing with this problem are also reviewed, and some further suggestions are provided.
\end{abstract}

Key words Rabies epidemiology, rabies transmission, Amazon region, rabies prevention and control, Latin America.

Veterinary Public Health and Zoonoses, Pan Amer-
ican Health Organization/World Health Organi-
zation, Washington, D.C., United States of Amer-
ica. Send correspondence and reprint requests to:
Cristina Schneider, Pan American Health Organi-
zation, World Health Organization, 525 23rd Street
Northwest, Washington, D.C. 20037-2895, United
States of America; telephone: (+1-202) 974-3190;
e-mail: schneidc@paho.org
University of Iguaçú, Rio de Janeiro, Brazil; and
Agricultural Research Institute of Rio de Janeiro
State, Departments of Health and Agriculture, Rio
de Janeiro State, Brazil.
Department of Zoology, Paulista State University,
Botucatu, São Paulo, Brazil.
Veterinary Public Health, Pan American Health
Organization/World Health Organization Coun-
try Office, Lima, Peru.
Health Surveillance and Disease Management,
Pan American Health Organization/World Health
Organization, Washington, D.C., United States of
America.
Pan American Foot-and-Mouth Disease Center
(PANAFTOSA), Pan American Health Organization/
World Health Organization, Rio de Janeiro, Brazil.
Fatal cases of human rabies transmitted by hematophagous (vampire) bats reached new heights in Latin America in 2004 (with 46 cases) and 2005 (55 cases) (1). Most cases occurred in the Amazon region of Brazil and Peru and in some remote communities of Colombia located a great distance from health services (2-7). Vampire bats are found only in Latin America $(8,9)$. Of the three known species-Diphylla ecaudata, Diaemus youngi, and Desmodus rotundus (the common vampire)—only the latter has been known to feed on mammals and thus has possibly transmitted rabies virus in the human outbreaks studied (9). Antigenic characterization carried out on viral strains isolated in several outbreaks reported that variant 3 was associated with this species $(7,10-13)$. Not all isolates from human rabies cases in Latin America have been characterized genetically; there have also been reports of other rabies virus variants related to different bat species that have been obtained from human samples $(14,15)$.

In 2004, for the first time in the history of the Regional Rabies Elimination Program coordinated by the Pan American Health Organization (PAHO), the number of human cases of rabies transmitted by wildlife (in most cases, the vampire bat) exceeded the number of cases transmitted by dogs (16). Since the 1980s, Latin American countries have been making major efforts to control dog-transmitted human rabies, and the number of cases has de- 
clined by nearly $90 \%$ (17). In 2005, there were 13 reported cases of dog-transmitted human rabies in Latin America, compared with 60 cases of bat-transmitted human rabies. Of the latter, 55 were transmitted by hematophagous bats and 5 by nonhematophagous bats (in Mexico). Of the cases involving vampire bats, 42 occurred in Brazil (41 in the Amazon region and 1 in another area), 7 in Peru, 3 in Colombia, 2 in Ecuador, and 1 in Bolivia (1).

This article reviews outbreaks of battransmitted human rabies, focusing on vampire bats, through an overview of the literature and by consulting three available databases. On the basis of this epidemiological information, the authors reexamine the subject from a more complex perspective and discuss possible factors related to this unexpected increase in reported human cases in the Amazon region, mainly in Brazil. Also reviewed are the control measures recommended to date to mitigate the problem. Following the discussion, suggestions are made, taking into account the special characteristics of the Amazon region.

\section{RABIES TRANSMITTED BY BATS TO HUMANS IN LATIN AMERICA}

The earliest colonists in the Americas reported human rabies cases suggesting transmission by vampire bats (18). The first outbreak of bat-transmitted human rabies in the literature was described in Trinidad in 1927, with diagnosis confirmed in 1931 (19). In this outbreak, 55 human deaths were recorded between 1929 and 1935 (20). The second recorded outbreak occurred in Mexico in 1951 (21).

Rabies control programs began to be organized in Latin America in the 1970s. The early 1980s marks the start of the
Regional Program for the Elimination of Human Rabies Transmitted by Dogs, coordinated by PAHO (22). A main feature of this Program was the Regional Information System for Epidemiological Surveillance of Rabies in the Americas (SIRVERA), designed for reporting cases of both human and animal rabies (1).

Table 1 summarizes information on possible outbreaks found in the literature, combined with data from Ministries of Health of Peru and Brazil (1-3, 5-7, 10, 13, 23-29). Additional information was requested from these two countries because they reported the largest number of human cases of rabies transmitted by bats in Latin America.

Figure 1 shows a timetable of possible outbreaks, featuring departments and states reporting five or more cases of battransmitted human rabies in a given year; Figure 2 shows the locations of the out-

TABLE 1. Timetable of bat-transmitted human rabies in Latin America, from the literature and official country data from Ministries of Health of Brazil and Peru

\begin{tabular}{|c|c|}
\hline Year and cases & Reference \\
\hline $\begin{array}{l}\text { 1970s } \\
\text { In 1975, outbreaks of bat-transmitted human rabies were reported in Peru ( } 13 \text { cases) in the Amazonas } \\
\text { department, in the Brazilian Amazon ( } 6 \text { cases) in Pará state, and in Suriname ( } 7 \text { cases). } \\
\text { In } 1977,5 \text { cases occurred in Pasco department, Peru. }\end{array}$ & $\begin{array}{c}6,23,24 \\
6\end{array}$ \\
\hline $\begin{array}{l}\text { 1980s } \\
\text { In 1984, } 15 \text { cases occurred in Amazonas department, Peru. } \\
\text { In 1985, } 19 \text { cases occurred in Ayacucho department, Peru. } \\
\text { In 1987, } 7 \text { cases occurred in Madre de Dios department, Peru. } \\
\text { In 1989, } 28 \text { cases occurred in Madre de Dios department, Peru. } \\
\text { Of these, } 24 \text { cases were from the same outbreak-the largest number of cases reported up to that time in a } \\
\text { single disease focus. } \\
\text { During this decade in Peru, a total of } 76 \text { cases were reported in the above-mentioned outbreaks ( } 69 \text { cases), } \\
\text { with } 7 \text { distributed throughout two departments over different years. } \\
\text { In Brazil during the } 1980 \text { s, } 34 \text { cases of bat-transmitted human rabies were reported, although there were } \\
\text { no reports of } 5 \text { cases or more from the same disease focus. } \\
\text { Among them was the outbreak with } 2 \text { cases in the state of Alagoas. }\end{array}$ & 6,25 \\
\hline $\begin{array}{l}\text { 1990s } \\
\text { In 1990, } 29 \text { cases were reported in Amazonas department, Peru. In the same year, there was an outbreak } \\
\text { in the Brazilian Amazon in Mato Grosso state, with } 5 \text { reported and } 3 \text { suspected cases. } \\
\text { In } 1991,9 \text { cases were reported in Amazonas department, Peru. } \\
\text { In } 1994,22 \text { cases were reported in Amazonas department, Peru. } \\
\text { In 1995, } 11 \text { cases were reported in Loreto department, Peru. } \\
\text { In } 1996,8 \text { cases were reported in Cusco department, Peru. } \\
\text { During this decade in Peru, a total of } 105 \text { cases were reported from the above-mentioned outbreaks } \\
\text { ( } 79 \text { cases) involving } 5 \text { or more cases in the same department, with } 26 \text { others distributed throughout } \\
8 \text { departments over different years. } \\
\text { In the } 1990 \text { s, other outbreaks involving fewer than } 5 \text { cases were reported in Brazil, with the total number of } \\
\text { cases in the country increasing to } 12 \text { cases in } 1991 \text { and to } 13 \text { cases in } 1992 \text {. }\end{array}$ & $\begin{array}{c}6,10,23 \\
6 \\
6 \\
6 \\
6 \\
\\
6 \\
2,28,29\end{array}$ \\
\hline $\begin{array}{l}2000 \text { to present } \\
\text { In } 2004,21 \text { cases were reported in two municipalities in Pará state, Brazil. In the same year, } 14 \text { cases } \\
\text { were reported in Chocó department, Colombia. An additional } 8 \text { cases were reported in } \\
\text { Amazonas department, Peru. } \\
\text { In Brazil in } 2005,17 \text { cases were reported in Pará state and } 24 \text { were reported in Maranhão state. } \\
\text { This year has shown the largest number yet of reported cases of bat-transmitted human rabies } \\
\text { in the Americas: Brazil ( } 42 \text { cases), Peru ( } 7 \text { cases), Colombia ( } 3 \text { cases), Ecuador ( } 2 \text { cases), and } \\
\text { Bolivia ( } 1 \text { case), for a total of } 55 \text { cases of human rabies transmitted by vampire bats. } \\
\text { An additional } 5 \text { cases of human rabies transmitted by nonvampire bat species occurred in Mexico. }\end{array}$ & $2,3,6,7,13$ \\
\hline
\end{tabular}


FIGURE 1. Timeline of outbreaks compiled from the literature and from departments and states with five or more cases of bat-transmitted human rabies in the same year, Latin America, 1975-2006

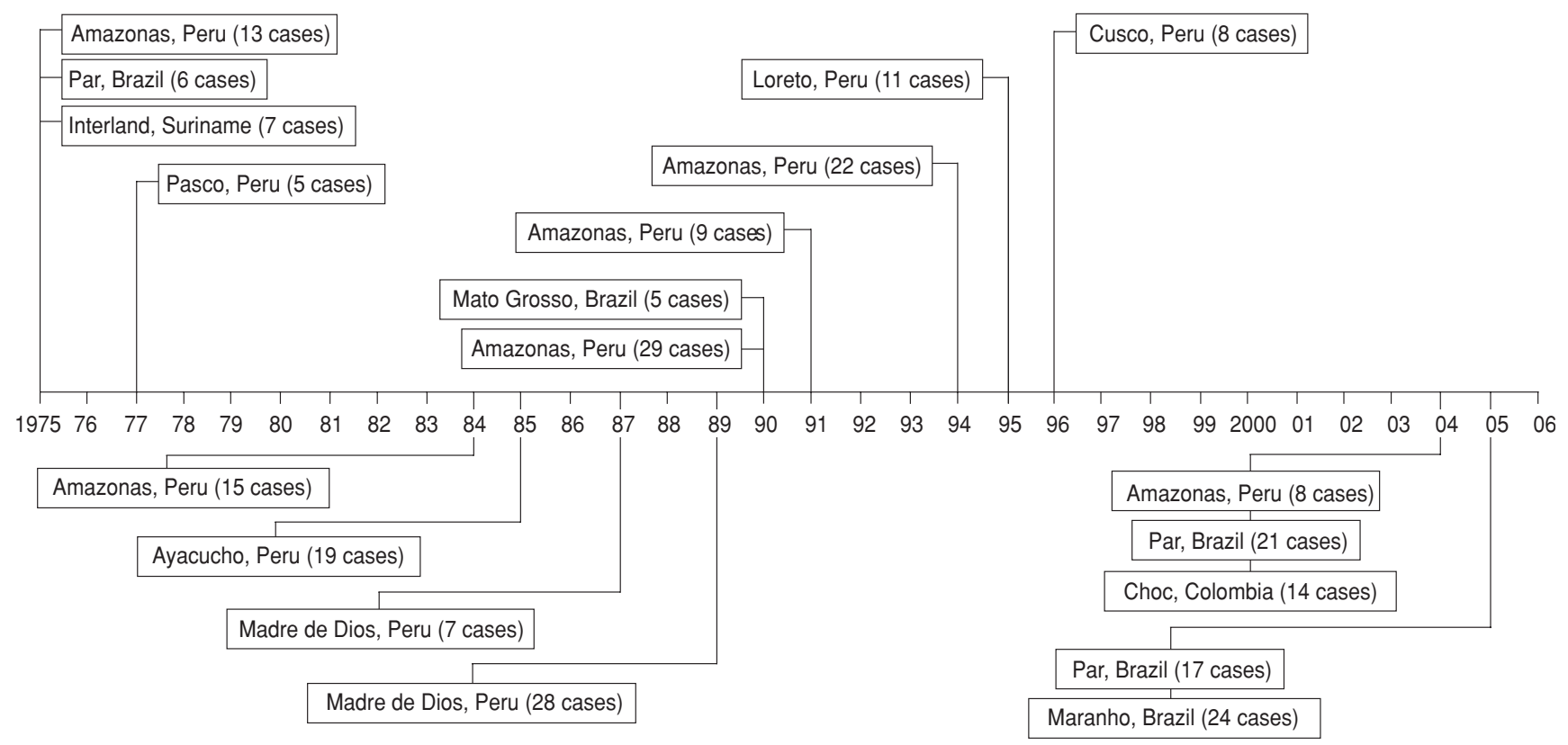

Source: Literature reviews, Ministry of Health of Brazil, 2007; Ministry of Health of Peru, 2007.

breaks. Figure 1 suggests higher concentrations of outbreaks with five or more reported cases in 1975, 1990, and 2005. Figure 3 shows the total annual number of cases in Peru and Brazil. Peru has been reporting annual peaks of 19-29 cases since the mid-1980s. Brazil, on the other hand, reported a maximum of 13 cases annually before the number increased to 22 in 2004 and to 42 in 2005.

A review of the literature through 1990 reported 330 cases of bat-transmitted human rabies in Latin America (26). These cases, along with PAHO data to the end of 2006, revealed 637 reported cases of bat-transmitted human rabies in Latin America (1). In 1996, SIRVERA started to distinguish among bat species (nonhematophagous versus hematophagous), reporting 199 human cases transmitted by bats during the period 1996-2006. Of these cases, $146(73 \%)$ were transmitted by vampire bats, $16(8 \%)$ by nonvampire bats, and 37 (19\%) with no species reported (Table 2) (1). Also worthy of recognition is the importance of isolated cases of bat-transmitted human rabies in general, including the number of cases transmitted by nonhematophagous bats shown in Table 1 as well as isolated cases transmitted by nonhematophagous bats in North America $(12,30)$. This article focuses on outbreaks in the rainforest.
There have been a number of accounts in Latin America of humans who were bitten by vampire bats but did not develop rabies. Naturally, the development of this disease depends on circulation of virus in the region as well as on access to prophylactic measures, among other variables. Events of this type have been reported in Belize; among indigenous peoples in Venezuela and Brazil; in river communities and agricultural settlements in the Brazilian Amazon states of Amazonas, Pará, and Amapá; in northeastern Brazil; in the Brazilian state of Maranhão; and among gold prospectors in Brazil and Venezuela (26, 31-38).

\section{POSSIBLE FACTORS ASSOCIATED WITH THE OCCURRENCE OF OUTBREAKS}

The problem of humans being bitten by vampire bats and thus at risk of rabies transmission has existed in Latin America for centuries, although recently there have been increased reports of human rabies transmitted by the common vampire bat $D$. rotundus, especially in the Amazon regions of Brazil and Peru.

A study of those outbreaks, for which a report was published with information on where they occurred, shows that most of them shared the same conditioning factors. We divide these factors into two interrelated groups: biological and nonbiological. Biological factors include the presence of vampire bats, the existence of adequate shelter for them, the availability of food sources, and the presence of rabies virus in the area. Nonbiological factors include the type of human productive process and changing patterns in such activities, working and living conditions, access to rabies prophylaxis, and measures being implemented to control bat populations.

Biological factors are among the conditions necessary for maintaining the chain of transmission in the wildlife cycle of bat-transmitted rabies. These factors constitute elemental rabies foci, where once humans dwell in the focus area, structural changes triggered by nonbiological or social factors make the disease emerge. For example, when humans go into a forest to prospect for gold, they introduce changes into that area, such as cutting down trees, bringing in noisy machinery, hunting animals for food, and sleeping in hammocks in exceedingly vulnerable housing where they serve as easy prey. These changes in the environment in turn can lead to changes in the type of species available as a food supply for vampire bats, which could lead to their attacking people. 
FIGURE 2. Geopolitical location of outbreaks with five or more cases of bat-transmitted human rabies in the same year, Latin America, 1975-2006

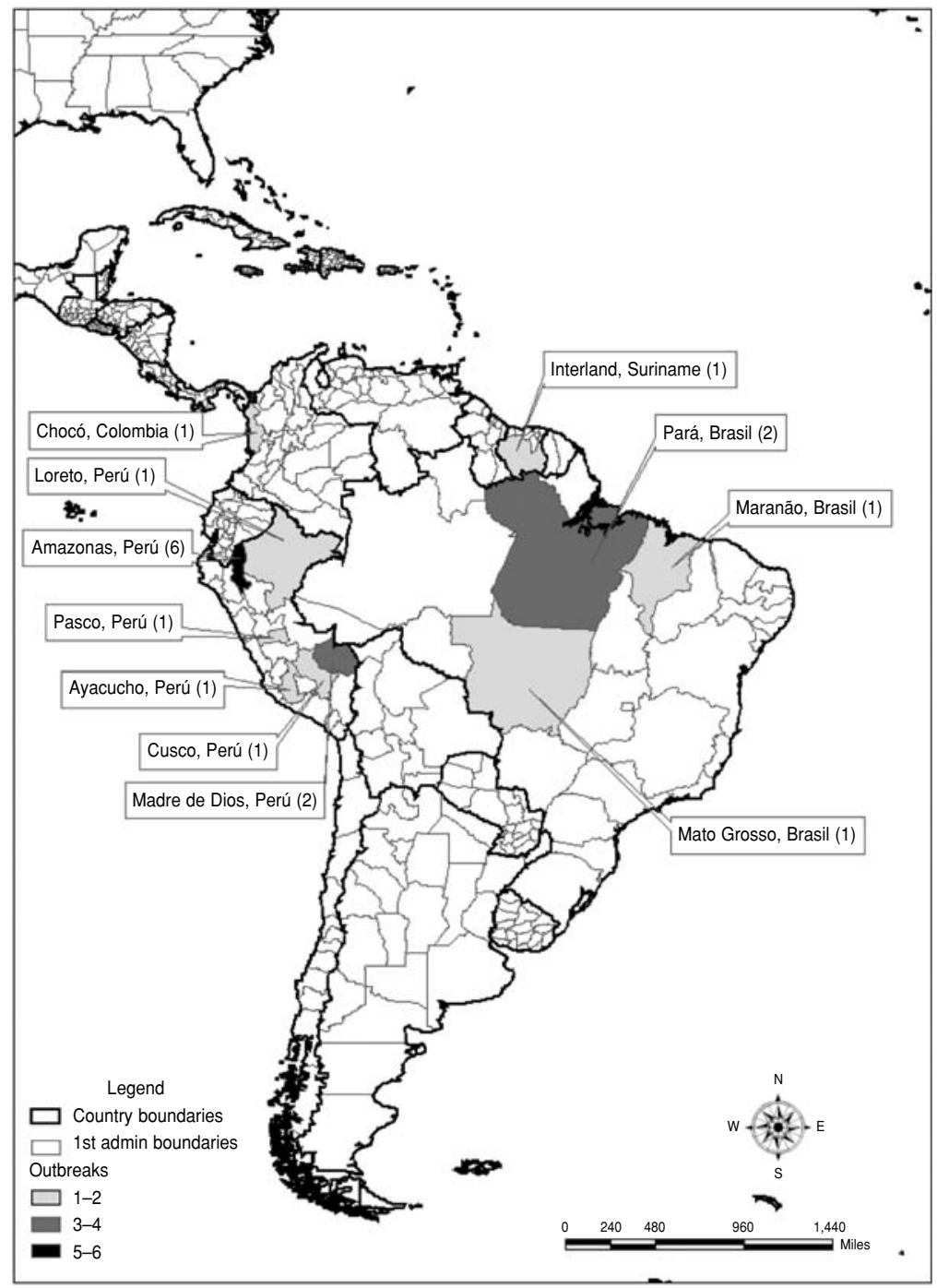

Source: Literature reviews, Ministry of Health of Brazil, 2007; Ministry of Health of Peru, 2007.

FIGURE 3. Total annual number of cases of bat-transmitted human rabies, Brazil and Peru, 1980-2006

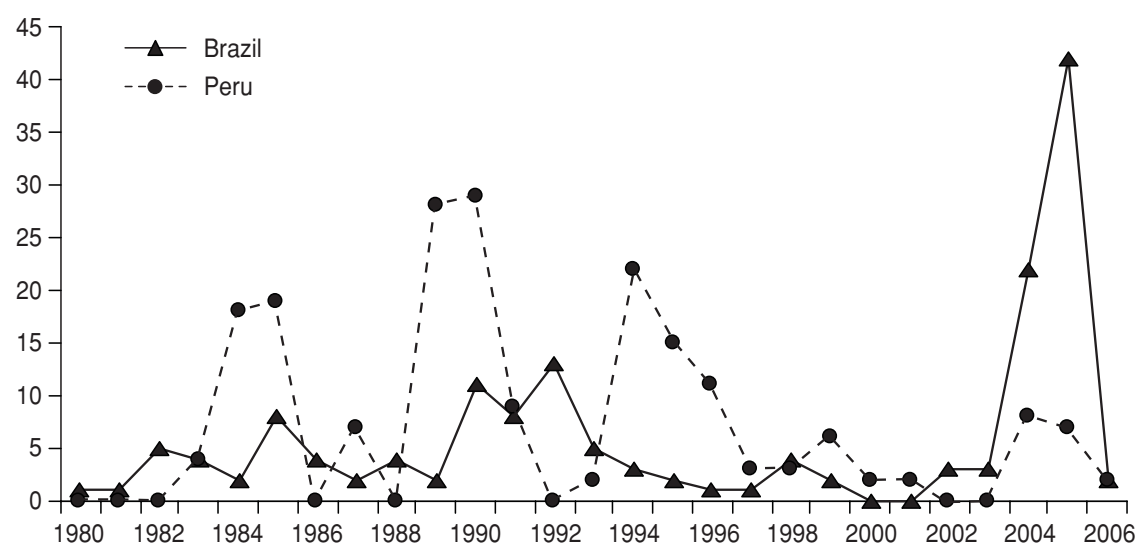

Source: Ministry of Health of Brazil, 2007; Ministry of Health of Peru, 2007.
A better understanding of the issue and what actually takes place during these outbreaks would make it possible to propose more specific control measures to reduce the number of deaths caused by this disease.

\section{Recurring nonbiological factors}

One study analyzed a set of eight outbreaks occurring around 1990 in Peru and Brazil (39). This analysis enabled the identification of certain factors recurring in most outbreaks:

1. They all occurred in small population groups in generally remote rural areas.

2. All the outbreak localities on which information is available had experienced a change in the type of human productive process taking place there, such as a gold rush, deforestation, or withdrawal of domestic animals.

3. All the communities had poor living conditions, including precarious housing.

4. None of them (at least where information was available) had access to health services offering rabies prophylactic treatment, nor did the inhabitants know that a bat bite could transmit rabies.

5. The practice of raising large domestic livestock was limited or nonexistent in these areas at the time of the outbreaks; in two cases, the outbreaks coincided with a recent end to livestock production.

Similar conditions have been observed in more recent outbreaks $(4,7)$, with reports of poor living conditions, vulnerable housing in remote areas (Figure 4), and difficulties accessing health services-for example, traveling for hours by motor boat to the next town (40-42).

\section{Vampire bat rabies in the Amazon region and natural disease foci}

In analyzing the population dynamics of bats infected with rabies in the Amazon region, it is helpful to review Pavlovsky's theory of natural disease foci, propounded in the 1930s (43). It proposed that the factors responsible for genesis of the foci originate in the components of an ecological equilibrium that maintains itself within a given biogeographical or environmental panorama and that can be individualized through the interrelated components of micro- 
TABLE 2. Cases of bat-transmitted human rabies, by species, Latin America, 1996-2006

\begin{tabular}{|c|c|c|c|c|c|c|c|c|c|c|c|c|c|}
\hline Country & Species & 1996 & 1997 & 1998 & 1999 & 2000 & 2001 & 2002 & 2003 & 2004 & 2005 & 2006 & Total \\
\hline \multirow[t]{3}{*}{ Argentina } & Vampire & $\ldots .^{a}$ & $\ldots$ & $\ldots$ & $\ldots$ & $\ldots$ & $\ldots$ & $\ldots$ & $\ldots$ & $\ldots$ & $\ldots$ & & $\ldots$ \\
\hline & Nonvampire & $\ldots$ & 1 & $\ldots$ & $\ldots$ & $\ldots$ & 1 & $\ldots$ & $\ldots$ & $\ldots$ & $\ldots$ & & 2 \\
\hline & Unspecified & $\ldots$ & $\ldots$ & $\ldots$ & $\ldots$ & $\ldots$ & $\ldots$ & $\ldots$ & $\ldots$ & $\ldots$ & $\ldots$ & $\ldots$ & $\cdots$ \\
\hline \multirow[t]{3}{*}{ Bolivia } & Vampire & $\ldots$ & $\ldots$ & $\ldots$ & $\ldots$ & $\ldots$ & $\ldots$ & $\ldots$ & $\ldots$ & $\ldots$ & 1 & $\ldots$ & 1 \\
\hline & Nonvampire & $\ldots$ & $\ldots$ & $\ldots$ & $\ldots$ & $\ldots$ & $\ldots$ & $\ldots$ & $\ldots$ & $\ldots$ & $\ldots$ & $\ldots$ & $\ldots$ \\
\hline & Unspecified & $\ldots$ & $\ldots$ & $\ldots$ & $\ldots$ & $\ldots$ & $\ldots$ & $\ldots$ & $\ldots$ & $\ldots$ & $\ldots$ & $\ldots$ & $\ldots$ \\
\hline \multirow[t]{2}{*}{ Brazil } & Vampire & $\ldots$ & $\ldots$ & $\ldots$ & $\ldots$ & $\ldots$ & $\ldots$ & 3 & 3 & 22 & 42 & 2 & 72 \\
\hline & Unspecified & 1 & $1^{b}$ & 4 & 2 & $\ldots$ & $\ldots$ & $\ldots$ & $\ldots$ & $\ldots$ & $\ldots$ & $\ldots$ & 8 \\
\hline \multirow[t]{3}{*}{ Chile } & Vampire & $\ldots$ & $\ldots$ & $\ldots$ & $\ldots$ & $\ldots$ & $\ldots$ & $\ldots$ & $\ldots$ & $\ldots$ & $\ldots$ & $\ldots$ & . \\
\hline & Nonvampire & 1 & $\ldots$ & $\ldots$ & $\ldots$ & $\ldots$ & $\ldots$ & $\ldots$ & $\ldots$ & $\ldots$ & $\ldots$ & $\ldots$ & 1 \\
\hline & Unspecified & $\ldots$ & $\ldots$ & $\ldots$ & $\ldots$ & . . & $\ldots$ & $\ldots$ & $\ldots$ & $\ldots$ & $\ldots$ & $\ldots$ & \\
\hline \multirow[t]{3}{*}{ Colombia } & Vampire & 3 & $\ldots$ & $\ldots$ & $\ldots$ & $\ldots$ & $\ldots$ & $\ldots$ & $\ldots$ & 14 & 3 & $\ldots$ & 20 \\
\hline & Nonvampire & $\ldots$ & $\cdots$ & $\ldots$ & $\ldots$ & . . & $\ldots$ & $\ldots$ & $\ldots$ & $\ldots$ & $\ldots$ & $\ldots$ & $\ldots$ \\
\hline & Unspecified & $\ldots$ & . . & $\ldots$ & $\ldots$ & . . . & $\ldots$ & $\ldots$ & $\ldots$ & $\ldots$ & $\ldots$ & $\ldots$ & $\ldots$ \\
\hline \multirow[t]{2}{*}{ Cuba } & Vampire & $\ldots$ & $\ldots$ & $\ldots$ & $\ldots$ & $\ldots$ & $\ldots$ & $\ldots$ & $\ldots$ & $\ldots$ & $\ldots$ & $\ldots$ & $\ldots$ \\
\hline & Nonvampire & $\ldots$ & $\ldots$ & $\ldots$ & $\ldots$ & 1 & $\ldots$ & $\ldots$ & 1 & $\ldots$ & $\ldots$ & $\ldots$ & 2 \\
\hline \multirow[t]{3}{*}{ Dominican Republic } & Vampire & $\ldots$ & $\ldots$ & $\ldots$ & $\ldots$ & $\ldots$ & $\ldots$ & $\ldots$ & $\ldots$ & $\ldots$ & $\ldots$ & $\ldots$ & $\ldots$ \\
\hline & Nonvampire & $\ldots$ & $\ldots$ & $\ldots$ & $\ldots$ & $\ldots$ & $\ldots$ & $\ldots$ & $\ldots$ & 1 & $\ldots$ & $\ldots$ & 1 \\
\hline & Unspecified & $\ldots$ & $\ldots$ & $\ldots$ & $\ldots$ & . . & $\ldots$ & $\ldots$ & $\ldots$ & $\ldots$ & . . & $\ldots$ & $\ldots$ \\
\hline \multirow[t]{3}{*}{ Ecuador } & Vampire & $\ldots$ & $\ldots$ & $\ldots$ & $\ldots$ & $\ldots$ & $\ldots$ & $\ldots$ & $\ldots$ & $\ldots$ & 2 & $\ldots$ & 2 \\
\hline & Nonvampire & $\ldots$ & $\ldots$ & $\ldots$ & $\ldots$ & $\ldots$ & $\ldots$ & $\ldots$ & $\ldots$ & $\ldots$ & $\ldots$ & $\ldots$ & $\ldots$ \\
\hline & Unspecified & $\ldots$ & $\ldots$ & $\ldots$ & $\ldots$ & $\ldots$ & $\ldots$ & $\ldots$ & $\ldots$ & $\ldots$ & $\ldots$ & $\ldots$ & $\ldots$ \\
\hline \multirow[t]{3}{*}{ El Salvador } & Vampire & $\ldots$ & . . & $\ldots$ & $\ldots$ & . . . & $\ldots$ & 1 & $\ldots$ & $\ldots$ & $\ldots$ & $\ldots$ & 1 \\
\hline & Nonvampire & $\ldots$ & $\ldots$ & $\ldots$ & $\ldots$ & $\ldots$ & $\ldots$ & $\ldots$ & $\ldots$ & $\ldots$ & $\ldots$ & $\ldots$ & $\ldots$ \\
\hline & Unspecified & $\ldots$ & $\ldots$ & $\ldots$ & $\ldots$ & $\ldots$ & $\ldots$ & $\ldots$ & $\ldots$ & $\ldots$ & $\ldots$ & $\ldots$ & $\ldots$ \\
\hline \multirow[t]{3}{*}{ Mexico } & Vampire & $\ldots$ & $\ldots$ & $\ldots$ & $\ldots$ & $\ldots$ & $\ldots$ & 1 & $\ldots$ & $\ldots$ & & $\ldots$ & 1 \\
\hline & Nonvampire & $\ldots$ & $\ldots$ & $\ldots$ & $\ldots$ & $\ldots$ & 1 & $\ldots$ & $\ldots$ & $\ldots$ & 5 & 1 & 7 \\
\hline & Unspecified & 6 & 2 & 7 & 4 & 2 & 1 & 2 & $\ldots$ & $\ldots$ & $\ldots$ & $\ldots$ & 24 \\
\hline \multirow[t]{6}{*}{ Nicaragua } & Vampire & $\ldots$ & $\ldots$ & $\ldots$ & 1 & $\ldots$ & $\ldots$ & $\ldots$ & $\ldots$ & $\ldots$ & $\ldots$ & $\ldots$ & 1 \\
\hline & Nonvampire & $\ldots$ & $\ldots$ & $\ldots$ & $\ldots$ & $\ldots$ & $\ldots$ & $\ldots$ & $\ldots$ & $\ldots$ & $\ldots$ & $\ldots$ & $\ldots$ \\
\hline & Unspecified & $\ldots$ & $\ldots$ & $\ldots$ & $\ldots$ & $\ldots$ & $\ldots$ & $\ldots$ & $\ldots$ & $\ldots$ & $\ldots$ & $\ldots$ & $\ldots$ \\
\hline & Vampire & $\ldots$ & $\ldots$ & $\ldots$ & $\ldots$ & $\ldots$ & $\ldots$ & 2 & $\ldots$ & $\ldots$ & $\ldots$ & $\ldots$ & 2 \\
\hline & Nonvampire & $\ldots$ & $\ldots$ & $\ldots$ & $\ldots$ & . . & $\ldots$ & $\ldots$ & $\ldots$ & $\ldots$ & . . & $\ldots$ & $\ldots$ \\
\hline & Unspecified & $\ldots$ & $\ldots$ & $\ldots$ & $\ldots$ & $\ldots$ & $\ldots$ & $\ldots$ & $\ldots$ & $\ldots$ & $\ldots$ & $\ldots$ & $\ldots$ \\
\hline & Unspecified & $\ldots$ & $\ldots$ & $\ldots$ & $\ldots$ & $\ldots$ & $\ldots$ & 1 & $\ldots$ & $\ldots$ & $\ldots$ & $\ldots$ & 1 \\
\hline \multirow[t]{3}{*}{ Peru } & Vampire & $11^{c}$ & 3 & 3 & 6 & 2 & 2 & $\ldots$ & $\ldots .^{c}$ & 8 & 7 & 2 & 44 \\
\hline & Nonvampire & $\ldots$ & $\ldots$ & 3 & . . & . . . & $\ldots$ & $\ldots$ & . . & $\ldots$ & $\ldots$ & $\ldots$ & 3 \\
\hline & Unspecified & $\ldots$ & $\ldots$ & $\ldots$ & 1 & $\ldots$ & $\ldots$ & $\ldots$ & $\ldots$ & $\ldots$ & $\ldots$ & $\ldots$ & 1 \\
\hline \multirow[t]{3}{*}{ Suriname } & Vampire & $\ldots$ & $\ldots$ & $\ldots$ & $\ldots$ & $\ldots$ & $\ldots$ & $\ldots$ & $\ldots$ & $\ldots$ & $\ldots$ & $\ldots$ & $\ldots$ \\
\hline & Nonvampire & $\ldots$ & $\ldots$ & $\ldots$ & $\ldots$ & $\ldots$ & $\ldots$ & $\ldots$ & $\ldots$ & $\ldots$ & $\ldots$ & $\ldots$ & $\ldots$ \\
\hline & Unspecified & $\ldots$ & $\ldots$ & 1 & $\ldots$ & $\ldots$ & $\ldots$ & $\ldots$ & $\ldots$ & $\ldots$ & $\ldots$ & $\ldots$ & 1 \\
\hline \multirow[t]{3}{*}{ Venezuela } & Vampire & $\ldots$ & . . & $\ldots$ & $\ldots$ & . . & $\ldots$ & $\ldots$ & $\ldots$ & 2 & $\ldots$ & $\ldots$ & 2 \\
\hline & Nonvampire & $\ldots$ & $\ldots$ & $\ldots$ & $\ldots$ & $\ldots$ & $\ldots$ & $\ldots$ & $\ldots$ & $\ldots$ & $\ldots$ & $\ldots$ & $\ldots$ \\
\hline & Unspecified & $\ldots$ & 1 & $\ldots$ & $\ldots$ & $\ldots$ & 1 & $\ldots$ & $\ldots$ & $\ldots$ & $\ldots$ & $\ldots$ & 2 \\
\hline Total & & 22 & 8 & 18 & 14 & 5 & 6 & 10 & 4 & 47 & 60 & 5 & 199 \\
\hline
\end{tabular}

Source: SIRVERA/PAHO, 2007.

b Data revised by Ministry of Health of Brazil.

c Data revised by Ministry of Health of Peru.

climate, flora, and fauna (44). These foci represent a biotype within a territory with certain specific landscape characteristics, one inhabited by animals that, under favorable environmental conditions, act as reservoirs for certain disease agents circulated among them without interruption by specific vectors. When humans penetrate or settle in these territories, they can become infected because they have stepped into the radius of action of these natural disease foci.
Elemental foci can be organized into a nuclear region, a peripheral region, and a region of dispersion, depending on the geographical distribution of the ecological and social components that are prerequisites of the disease (45). When there is an enabling environment favoring the agent's particular characteristics, the agent begins to replicate and disperse. On the other hand, when conditions become unfavorable, the foci regress, leaving behind small foci where the causative agent has been able to locate the necessary conditions for its survival (i.e., maintenance of the infection) over long periods. These organisms then continue to circulate the infectious agents. Remaining are the so-called secondary foci.

We suggest that many diseases originally involved natural foci, maintaining a chain of transmission exclusively among wildlife with no human presence. The wildlife cycle of rabies in bats aligns well with this hypothesis, which was invoked 


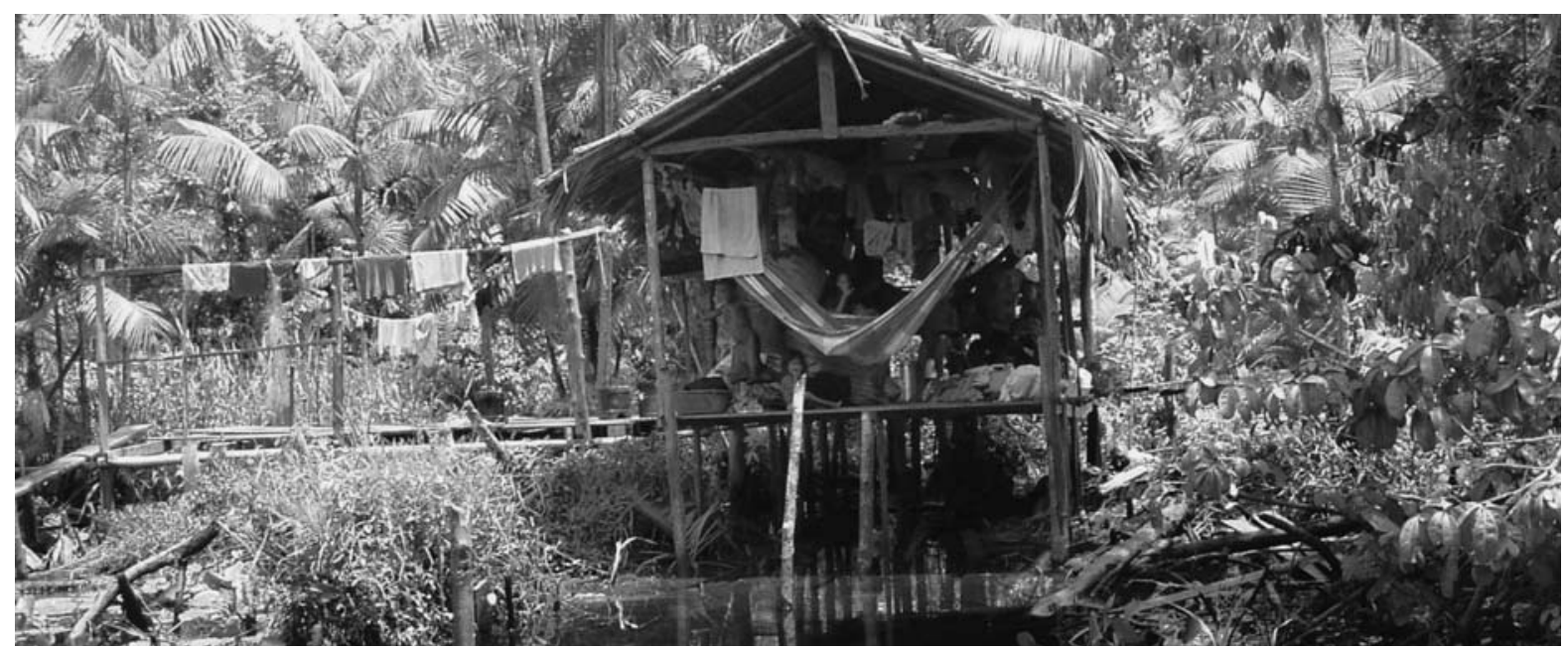

Source: Photo courtesy of W. Uieda.

in one study on a bovine rabies outbreak in Latin America (46). Many of the areas considered to be at risk for human rabies transmitted by vampire bats-for example, newly cleared land and areas attracting gold prospectors-could be considered natural rabies foci that have been penetrated by humans in pursuit of a specific economic objective $(26,47,48)$.

The process of disease emergence can be influenced by the environment as well as by physical and ecological changes (49, 50). Diseases can arise both naturally and anthropologically, but the primary event is always physical contact between the potential pathogen and human beings (51). Three classifications of the macrolandscape in the Amazon have been proposed, all based on socioenvironmental characteristics: natural landscapes, landscapes disturbed by humans, and constructed landscapes (52). Any environmental imbalance will trigger either a reduction or uncontrolled growth among animal populations, be they vertebrate or invertebrate, which may act as potential disease reservoirs and transmitters (53).

\section{Behavior of bat populations in the Amazon region}

Unlike other regions of Brazil where livestock are the principal food source for the common vampire bat, in the Amazon region there is no single main food source but rather several small ones-for example, wildlife, hens, dogs, and people $(54,55)$. Because caves are rare in the Amazon rainforest of Brazil,
Desmodus colonies roost in hollow trees. Their colonies are probably about the same size as those in Costa Rica's rainforest, where $D$. rotundus colonies composed of 12 adult females, their young, and a dominant male, were found in hollow trees $(56,57)$.

Common vampire bats probably reproduce throughout the year as long as they have a regular food supply $(58,59)$. In the Amazon region, since food is not very abundant and their shelters in hollow trees are small, the bat population does not usually grow to be very large. In fact, in this undisturbed natural forest environment, the population density will remain low, making them almost rare $(54,60,61)$. However, numbers could grow if the food source increasesfor example, as a result of recent livestock-raising activities in the area. If such activity is later withdrawn, food sources for the vampire bat will diminish, and this change could result in increased recourse to biting people.

Bats are a primary reservoir for rabies virus in the world (30). It could be argued that rabies helps control bat populations. Natural rabies infection in all mammalian species generally causes an acute fatal illness, though rabies antibodies have been detected in apparently healthy species, including the vampire bat (62-64). When the population increases due to an abundant food supply and a shortage of natural predators, the resulting overpopulation generates stress, which can lead to disruption in the internal balance of microbiota and hence to dispersion, thus facilitating viral transmission during fights $(48,64)$. Bats have probably evolved by selecting special characteristics to contend with infectious diseases.

\section{The rising number of cases in Brazil}

Unlike Peru, which reported outbreaks of around 20 cases or more at different times between 1980 and 2004, Brazil reported no more than 5 bat-transmitted cases of rabies in any single outbreak, or 13 cases per year for the entire country. However, Brazil reported 22 cases in 2004 and 42 in 2005 (2). Is there really an increased risk of human rabies transmitted by vampire bats at the local level in Brazil?

A mathematical model was developed to estimate the force of infection where no control measures were in place (65). Field work for this study was carried out in Maranhão, Brazil, in 1994. Results showed 0.0096 bite by infectious rabiestransmitting bats per person per year, meaning that one case of bat-transmitted human rabies could be expected for every 100 persons living in a situation similar to the one studied (65). According to a more recent study, there were 21 cases in the state of Para during the 2004 Brazilian outbreaks; pre- or postexposure vaccines were administered to 2396 people (3). If one considers this group as the population at risk in the focus area, the number yields a proportion of 1 case for every 114 individuals at risk, which is very similar to the results estimated in the mathematical model. It should be 
emphasized that once the Brazilian government became aware of the outbreak, it took intersectoral action at several different levels to control it (3). In a 1994 cross-sectional study conducted in Maranhão, results showed that $41.1 \%$ of the people interviewed had been bitten by a vampire bat (26). In 2005, during an outbreak of human rabies transmitted by the common vampire bat in the same municipality in Maranhão, another crosssectional study found that $42 \%$ of the people interviewed had been bitten by a bat (5) - almost the same number found a decade earlier.

Comparison of the 1994 study with the more recent one suggests that the situation of people being bitten by bats had not changed very much at the local level. Moreover, the number of cases in the 2004 outbreaks was very close to the estimates from the mathematical model. So what could have changed between 1994 and 2004?

These observations provoke various topics of discussion. One might involve gradual improvements in Brazilian health and information systems since implementation of the Unified Health System (SUS) in 1988. Decentralization is a key feature of the SUS, which has resulted in increased response capacity at state and municipal levels as well as emphasis on training in epidemiological surveillance and improvements in information systems at all levels (66). In addition, Brazil currently reports cases involving epidemiological linkage, whereas in the 1990s the only deaths reported were those involving a death certificate $(4,23)$. Among other factors, these reports could contribute to greater awareness of what is going on in remote areas of the country. On the subject of the emergence and reemergence of infectious diseases, it has been suggested that a major factor is probably the very attention being paid to this subject nowadays (67).

Another factor of change in the Brazilian picture might be an increase in risk situations that alter the behavior of the Desmodus population - for example, clearing new land for economic reasons. In 1990, when an outbreak occurred in Mato Grosso with five reported cases, the annual rate of deforestation in Brazil's Amazon region was 13730 square kilometers, whereas by 2004 that figure had climbed to 27429 square kilometers-with the highest rates in the states of Mato Grosso and Pará (68).
The agricultural frontier in Brazil's Amazon region is now being cleared to make way for livestock raising and soybean cultivation. Unbridled occupation of the region has resulted in low agricultural productivity, poor quality of life for the local population, and an increasing impact on the environment (69).

\section{Prevention and control measures to reduce the number of deaths from human rabies transmitted by vampire bats}

Given the nature of the problem, the prevention and control of bat-transmitted rabies should involve not only health and agriculture but also the environment, education, housing, infrastructure, and other sectors. The recommendations made on this subject in recent decades have all emphasized an intersectoral approach.

In 1991, after major outbreaks in Peru and Brazil, PAHO organized an expert meeting that produced recommendations encouraging preexposure prophylactic treatment among high-risk populations as well as postexposure treatment for persons bitten by bats, control of bat populations, information and education for populations at risk, and epidemiological surveillance (70). The same year, the Brazilian Ministry of Health started an intersectoral multidisciplinary project to deal with these issues. In an expert meeting, four levels of risk situations were defined and actions were outlined for eventual implementation at each level (71).

A mathematical model was developed to study different control measures (preand postexposure vaccination, control of bat populations, or a combination of the two) to find out which would work best in terms of reducing the risk of human rabies in remote areas where people are constantly at risk of being bitten by bats (26). Recommendations on what would most reduce that risk involved a combination of bat population control and preexposure prophylaxis. This strategy was recommended for small, remote, highrisk areas but not for the entire Brazilian Amazon.

In 2004, the Brazilian Ministry of Health and PAHO co-organized a meeting to discuss an intersectoral approach to deal with the outbreaks occurring in Pará and to propose recommendations on how to handle them (72). In addition to a renewed emphasis on the recommenda- tions made at previous meetings, further emphasis was placed on the importance of working with community-level health workers to identify local people who had been bitten and to ensure an adequate supply of immunobiologicals.

In 2006, PAHO - together with several other institutions-convened the Expert Consultation on Bat-transmitted Rabies in the Amazon Region (73). The ensuing recommendations included several similar to those made at previous meetings as well as new ones promoting research on schemes facilitating the logistics of administering rabies prophylaxis, getting communities involved, and ensuring respect for the local culture and creating commissions at central and local levels to devise coordinated local strategies involving the health, agriculture, education, and environmental sectors.

Recommendations have been in place for some 20 years regarding what to do in such situations, and they are being implemented to the extent that national, state and departmental, and local governments are able to respond-including joint actions by the health and agricultural sectors, with support from academic institutions and international organizations $(3,4,7,10,13,23,25,74,75)$. The cost of these measures is high, both to maintain the teams working in remote areas and to procure human cell culture vaccines, which governments in Latin America usually provide free of charge. In an emergency, resources are often available for control measures in the midst of an outbreak, but preventive measures and ongoing monitoring in atrisk areas have to compete with many other health problems in the Amazon region, such as malaria, AIDS, yellow fever, and others.

\section{Difficulties in implementing measures in the Amazon region}

The Amazon basin spans sections of eight countries, covering 6.1 million square kilometers or $34 \%$ of the South American continent, with a population density (including its indigenous population) of fewer than five inhabitants per square kilometer. At the same time, it is blessed with $60 \%$ of the tropical rainforest remaining on Earth, and it harbors more biodiversity than practically any other place in the world (76). It has been estimated that only in the Brazilian Amazon a traditional population of six million- 
indigenous peoples, river dwellers, and others-lives by extrativism or small-scale subsistence agriculture. These people are more vulnerable to infectious diseases related to the environment, and they experience greater difficulty accessing health services (52). Many of these communities have their own beliefs and traditional medicines. During the 2005 outbreak of bat-transmitted human rabies in Ecuador, the population of the province of Pastaza, where the cases occurred, consisted of some 40000 inhabitants, with a density of 2.4 habitants per square kilometer; almost half of this population was indigenous, involving seven different nations (41).

What can be done in such a complex situation? The following thematic approaches are suggested:

- A multidisciplinary and interprogrammatic approach,

- Intersectoral coordination, and

- Community participation.

Only after understanding all aspects of the problem-especially human interaction with nature, which takes on special importance in that it involves the largest ecological reserve on the planetis it possible to even think of intervening.

The prevention of diseases transmitted by wildlife is feasible when there is adequate monitoring of environmental risks and the presence of rabies virus. One study that analyzed the behavior of Desmodus sp. in the Atlantic Forest of Brazil and bovine rabies concluded that, in order to understand the role of environmental changes in disease emergence, it is necessary first to compile an integrated picture from the perspective of different branches of biology, anthropology, and sociology (77).

Monitoring possible risk situations such as clearing land and prospecting for gold, as well as other changes in human productive processes, was taken into account in the recommendations made at a 1991 consultation (71). This kind of monitoring can be supplemented with information exchange between the health and agricultural sectors regarding rabies cases and bat bites in humans and animals, which could then help to anticipate possible events and thus make it possible to step in before an outbreak has started $(73,77)$.

Many areas where bats are currently biting people already have control programs in place for malaria or other diseases, so that health agents are locally involved who could implement interprogrammatic activities. These agents play an important role in identifying the problem and working with local communities to impress upon them the importance of preventing rabies. Since the local people in these remote areas are frequently bitten by vampire bats, it would be necessary to introduce the recommended preexposure prophylaxis. In addition, this practice should be accompanied by specific antibody-level detection to know when a booster vaccine is needed, which at present is very difficult to obtain. Making educational programs available to local populations in their own language and based on their own culture is also important.

Support from decision makers in the different sectors is imperative, along with community participation. Together, these factors constitute the foundation of the current recommendations. The basic mea- sures for dealing with outbreaks have been defined in other forums and in the aforementioned studies, but a lot remains to be learned about the risk of emerging diseases, particularly the dynamics of viruses like rabies and other zoonotic diseases actively circulating in complex communities such as we see in the Amazon region.

Finally, what is most important is the need to keep striving for a better quality of life for Amazon populations and for better access to health services and education, to guarantee and democratize environmental conditions favorable to life that have already been secured over successive stages of development, and to mitigate the negative consequences of unbridled development. The increase in the number of cases of bat-transmitted human rabies in the Amazon region is an example of the need for progress in this area. These rabies cases are only one of the many health problems Amazon populations face, especially those living in remote areas. These groups are largely neglected in terms of their access to health care, adequate housing, and acceptable living conditions.

Acknowledgments. The authors thank Ana Maria Navarro from the Ministry of Health of Peru and Rosely Cerqueira Oliveira and Lucia Montebello Pereira from the Ministry of Health of Brazil, who provided information for this study. Special thanks to Astrid Pimentel for reviewing the references and to Eutímio González for reviewing the literature for the PAHO CD on this subject. Additional thanks go to intersectoral staff in the countries for their work during the many rabies outbreaks in remote areas.

\section{REFERENCES}

1. Organización Panamericana de la Salud. Sistema de Información y Vigilancia Epidemiológica para la Rabia en las Américas (SIRVERA). Available from: http://sirvera. panaftosa.org.br/Login.aspx?ReturnUrl $=\% 2 \mathrm{f}$ default.aspx\%3fIdioma\%3dp\&Idioma=p. Accessed 14 May 2007.

2. Secretaria de Vigilância em Saúde, Ministério da Saúde, Brasil. Coordenação Geral de Doenças Transmissíveis. Casos de raiva humana por espécie agressora, Brasil 1986-2007 (parcial). Brasilia: Ministério da Saúde; 2007.

3. Oliveira RC. Outbreak of human rabies transmitted through bats in the Pará, Brazil. In RITA XV. Proceedings of the XV International Conference on Rabies in the Americas (RITA
XV); 2004 Oct 31-Nov 4; Santo Domingo, Dominican Republic: 2004. P. 96.

4. Rosa ES, Kotait I, Barbosa TF, Carrieri ML, Brandão PE, Pinheiro AS, et al. Bat-transmitted human rabies outbreaks, Brazilian Amazon. Emerg Infect Dis. 2006;12(8):1197-202.

5. Knegt LV, Renoiner EIM, Araújo WN, Wada MY, Almeida MAB, Santos HJ, et al. Prevalence study on vampire-bat (Desmodus rotundus) bites in a rural population following an outbreak of rabies-related deaths-Maranhão State, Brazil, 2005. In: RITA XVII. Annales of the XVII International Conference on Rabies in the Americas; 2006 Oct 15-20; Brasília, Brazil. Brasília: Ministry of Health; 2006. P. 45.
6. Dirección General de Salud de las Personas, Ministerio de Salud, Perú. Casos de rabia humana transmitida por animales silvestres. Lima: Ministerio de Salud; 2007.

7. Valderrama J, García I, Figueroa G, Rico E, Sanabria J, Rocha N, et al. Brotes de rabia humana transmitida por vampiros en los municipios de Bajo y Alto Baudó, departamento del Chocó, Colombia 2004-2005. Biomédica. 2006;26(3):387-96.

8. Flores-Crespo R, Arellano-Sota C. Biology and control of the vampire bat. In: Baer GM, ed. The natural history of rabies. 2nd ed. Boca Raton, FL: CRC Press; 1991. Pp. 461-76.

9. Greenhall AM. Ecology and bionomics of vampire bats in Latin America. In: Greenhall 
AM, Artois M, Fekadu M, eds. Bats and rabies. Lyon, France: Fondation Marcel Mérieux; 1993. Pp. 3-57.

10. Lopez A, Miranda P, Tejada E, Fishbein DB Outbreak of human rabies in the Peruvian jungle. Lancet. 1992;339(8790):408-11.

11. Warner CK, Zaki SR, Shieh WJ, Whitfield SG, Smith JS, Orciari LA, et al. Laboratory investigation of human deaths from vampire bat rabies in Peru. Am J Trop Med Hyg. 1999;60(3): 502-7.

12. Messenger SL, Rupprecht CE, Smith SJ. Bats, emerging virus infections and the rabies paradigm. In: Thomas HK, Fenton MB, eds. Bat ecology. Chicago: The University of Chicago Press; 2003. Pp. 622-79.

13. Wada MY, Begot AL, Noronha SLB, Almeida IF, Lima RJS, Santos LBC, et al. Investigação de surto de raiva humana no município de Portel-Pará, março/abril de 2004. SVS Bol Eletrônico Epidemiol. 2006;4(6):1-5. Available from: http://portal.saude.gov.br/portal/ arquivos/pdf/boletim_eletronico_06_ano04. pdf. Accessed 25 June 2007.

14. Favoretto SR, Carrieri ML, Cunha EMS, Aguiar EAC, Silva LHQ, Sodré MM, et al. Antigenic typing of Brazilian rabies virus samples isolated from animals and humans, 1989-2000. Rev Inst Med Trop São Paulo. 2002; 44(2):91-5

15. Velasco-Villa A, Orciari LA, Juárez-Islas V, Gómez-Sierra M, Padilla-Medina I, Flisser A et al. Molecular diversity of rabies viruses associated with bats in Mexico and other countries of the Americas. J Clin Microbiol. 2006;44: 1697-710.

16. Schneider MC, Belotto A, Leanes LF, Correa E, Tamayo H, Medina G, et al. Situación epidemiológica de la rabia humana transmitida por perros en América Latina en 2004. Bol Epidemiol OPS. 2005;26(1):2-4.

17. Belotto A, Leanes LF, Schneider MC, Tamayo $\mathrm{H}$, Correa E. Overview of rabies in the Americas. Virus Res. 2005;111(1):5-12.

18. Greenhall AM. Ethology and ecology of vampire bats. In: Pan American Health Organization, ed. Final report of the Expert Consultation on the Care of Persons Exposed to Rabies Transmitted by Vampire Bats; 1991 Apr 2-5; Washington, D.C. Washington, D.C.: PAHO; 1991. Pp. 11-7.

19. Baer GM. The natural history of rabies. 2nd. ed. Boca Raton, FL: CRC Press; 1991.

20. Verteuil E, Urich FW. The study and control of paralytic rabies transmitted by bats in Trinidad, British West Indies. R Soc Trop Med Hyg. 1935;4(29):317-51.

21. Málaga AA, Campillo SC. Rabia humana transmitida por murciélagos: confirmación de primer caso en México. Bol Of Sanit Panam. 1957;42(6):567-70.

22. Organización Panamericana de la Salud. Estrategia y plan de acción para la eliminación de la rabia urbana en América Latina para el final de la década de 1980. In: I Reunión de Directores de Programas Nacionales de Control de la Rabia; 1983 Dic 12-14; Guayaquil, Ecuador. Available from: Organización Panamericana de la Salud. Estrategia y plan de acción para la eliminación de la rabia urbana en América Latina para el final de la década de 1980. In: I Reunión de Directores de Programas Nacionales de Control de la Rabia 1983 Dic 12-14; Guayaquil, Ecuador. Available from: http:/ /www.panaftosa.org.br/Comp/ Zoonoses/Raiva/doc/plan_rabia_05-09.pdf Accessed 7 April 2008.

23. Schneider MC. Epidemiological situation of human rabies transmitted by bats in Brazil. Probable outbreak of bat-transmitted human rabies at Apiacás, Mato Grosso. In: Pan American Health Organization, ed. Final report of the Expert Consultation on the Care of Persons Exposed to Rabies Transmitted by Vampire Bats; 1991 Apr 2-5; Washington, D.C Washington, D.C.: PAHO; 1991. Pp. 56-75. Available from: http://www.paho.org/cd media/hdmvp01/docs.rabia/docs7/22\%5B1 \%5D.\%20Situaci\%F3n\%20epi\%20Brasil.pdf. Accessed 15 November 2007.

24. Verlinde JD, Li-Fo-Joe E, Versteeg J, Dekker SM. A local outbreak of paralytic rabies in Surinam children. Trop Geogr Med. 1975;27(2): 137-42.

25. López A. Report of the outbreaks of human rabies in Peru. Human outbreak in Madre de Dios. In: Pan American Health Organization, ed. Final report of the Expert Consultation on the Care of Persons Exposed to Rabies Transmitted by Vampire Bats; 1991 Apr 2-5; Washington, D.C. Washington, D.C. PAHO; 1991. Pp. 47-55. Available from: http:/ / www.scielo. $\mathrm{br} /$ scielo.php?script=sci_arttext\&pid=S0102 311X2001000600038\%094. Accessed 15 November 2007

26. Schneider MC. Rabia humana transmitida por murciélago hematófago en Brasil: modelo de transmisión y acciones de control. [PhD dissertation]. México, D.F.: Instituto Nacional de Salud Pública; 1996. Available from: http:// www.scielo.br/scielo.php? script $=$ sci arttext\&pid=S0102-311X2007000900013\&lng= pt\&nrm=iso\&tlng=pt. Accessed 25 October 2007.

27. Schneider MC. Reflexiones sobre los modelos para el estudio de los brotes de rabia humana por murciélago. Cad Saúde Pública. 1995;11(2): 291-304.

28. Gonçalves MAS, Sá-Neto RJ, Brazil TK. Outbreak of aggressions and transmission of rabies in human beings by vampire bats in northeastern Brazil. Rev Soc Bras Med Trop. 2002;35(5):461-4.

29. Uieda W, Harmani NMS, Silva MMS. Raiva em morcegos insetívoros (Molossidae) do sudeste do Brasil. Ver Saúde Pública. 1995;29: 393-7.

30. Rupprecht C, Hanlon C, Hemachudha T. Rabies re-examined. Lancet Infect Dis. 2002;2(6) 327-43.

31. MacCarthy T. Human depredation by vampire bats (Desmodus rotundus), following a hog cholera campaign. Am J Trop Med Hyg. 1989; 40(3):320-22.

32. Almansa JC, García RC. Incidencia del murciélago hematófago Desmodus rotundus sobre los indígenas Yanomami de Venezuela. Donana Acta Vertebr. 1980;7(1):113-7.

33. Uieda W, Paleari LM, Lima RJS, Begot AL, Ribeiro JR, Campos ACR, et al. Aspectos ecológicos das agressões humanas por morcegos hematófagos na região norte do Brasil. Final report. Universidade Estadual Paulista, Botucatu, Brazil. São Paulo: Fundação de Amparo a Pesquisa do Estado de São Paulo; 2002.

34. Uieda W, Cruz RH, Andrade MA, Carneiro PN Jr, Silva EP, Nunes IF, et al. Controle das agressões causadas pelo morcego hematófago
Desmodus rotundus a índios na região amazônica. In: FUNASA. Anais da I Mostra Nacional de Saúde Indígena: Gente que Faz; 2006 Nov 15-17; Brasília, Brazil: Fundação Nacional de Saúde; 2006. P. 68.

35. Costa MB, Bonito RF, Nishioka SA. An outbreak of vampire bat bite in a Brazilian village. Trop Med Parasitol. 1993;44:219-20.

36. Schneider MC, Aron I, Santos-Burgoa C, Uieda W, Ruiz-Velasco S. Common vampire bat attacks on humans in a village of the Amazon region of Brazil. Cad Saúde Pública. 2001; 17(6):1531-6.

37. Coelho GE. Aspectos relacionados às agressões humanas por morcegos hematófagos, potenciais transmissores da raiva, no estado de Roraima, Brasil. Brasília: Departamento de Saúde Coletiva, Universidade de Brasília; 1995.

38. Caraballo-H AJ. Outbreak of vampire bat biting in a Venezuelan village. Rev Saúde Pública. 1996;30(5):483-4.

39. Schneider MC, Burgoa CS. Algunas consideraciones sobre la rabia humana transmitida por murciélago. Salud Pública Mex. 1995;37(4): 354-62.

40. Montebello L. Situação epidemiológica no Brasil: ciclo silvestre. Presentado en Consulta de Expertos sobre Rabia Transmitida por Murciélagos Hematófagos en la Región Amazônica: paneles técnicos; 2006 Oct; Brasília Brasil. Available from: http://www.paho.org/ Spanish/AD/DPC/VP/rabia-murcielagos. htm. Accessed 4 April 2008.

41. Paredes C. Situação de los brotes recientes en el Equador. Presentado en Consulta de Expertos sobre Rabia Transmitida por Murciélagos Hematófagos en la Región Amazônica: paneles técnicos; 2006 Oct; Brasília, Brasil. Available from: http://www.paho.org/Spanish/ $\mathrm{AD} / \mathrm{DPC} / \mathrm{VP} /$ rabia-murcielagos.htm. Accessed 4 April 2008

42. Oliveira RC. Raiva tranmitida por morcegos: Recomendações 2004. Presentado en Consulta de Expertos sobre Rabia Transmitida por Murciélagos Hematófagos en la Región Amazónica: paneles técnicos; 2006 Oct; Brasília Brasil. Available from: http://www.paho.org/ Spanish/AD/DPC/VP/rabia-murcielagos. htm. Accessed 4 April 2008.

43. Pavlovsky EN. Natural nidality of transmissible diseases in relation to landscape epidemiology of zooanthroponoses. 1967 ed. Moscow: Peace Publishers; 1967.

44. Pifano F. Algunos aspectos en la ecología y epidemiología de las enfermedades con focos naturales en el área tropical, especialmente en Venezuela. Caracas: Ministerio de Sanidad y Asistencia Social; 1969.

45. Sinnecker H. The epidemic and epizootic process at work. In: Sinnecker H, ed. General epidemiology. London: John Wiley \& Sons; 1976.

46. Málaga AA, Samamé BH, Gonzáles S. Constatación de un nido natural de rabia en el Alto Ucayali, Departamento de Loreto. Bol Divul IVITA. 1971;4

47. Daszak P, Cunningham AA, Hyatt AD. Anthropogenic environmental change and the emergence of infectious diseases in wildlife. Acta Trop. 2001;78:103-16.

48. Kahn LH. Confronting zoonoses, linking human and veterinary medicine. Emerg Infect Dis. 2006;12(4):556-61. Available from: http:/ / www.cdc. gov/ncidod/EID/vol12no04/05 0956.htm. Accessed 2 April 2007. 
49. Patz JA, Graczyk TK. Effects of environmental change on emerging parasitic diseases. Int J Parasitol. 2000;30:1395-405.

50. Patz JA, Daszak P. Unhealthy landscapes: policy recommendations on land use change and infectious disease emergence. Environ Health Perspect. 2004;112(10):1092-8.

51. McMichael AJ, Woodruff RE, Hales S. Climate change and human health: present and future risks. Lancet. 2006;367(9513):859-69.

52. Confalonieri UEC. Saúde na Amazônia: um modelo conceitual para a análise de paisagens e doenças. Estud Av. 2005;19(53):221-36.

53. Woolhouse ME. Population biology of emerging and re-emerging pathogens. Trends Microbiol. 2002;10(10 Suppl):S3-7.

54. Greenhal AM. Feeding and feeding behavior. In: Greenhal AM, Schmidt U, eds. Natural history of vampire bats. Boca Raton, FL: CRC Press; 1988. Pp. 111-31.

55. Uieda W. História natural dos morcegos hematófagos no Brasil. In: Pacheco SM, Marques RV, Esberard CEL, eds. Morcegos no Brasil: biologia, sistemática, ecologia e conservação. Porto Alegre, Brasil: Armazém Digital; 2008. Pp. 179-98.

56. Wilkinson GS. The social organization of the common vampire bat. II. Mating system, genetic structure, and relatedness. Behav Ecol Sociobiol. 1985;17:123-34

57. Wilkinson GS. Social organization and behavior. In: Greenhal AM, Schmidt U, eds. Natural history of vampire bats. Boca Raton, FL: CRC Press; 1988. Pp. 85-97.

58. Schmidt C. Reproduction. In: Greenhal AM, Schmidt U, eds. Natural history of vampire bats. Boca Raton, FL: CRC Press; 1988. Pp. 99-109.

59. Bredt A, Uieda W, Magalhães ED. Morcegos cavernícolas da região do Distrito Federal, centro-oeste do Brasil (Mammalia, Chiroptera). Rev Bras Zool. 1999;16(3):731-70.

60. Crespo JA, Vanella JM, Blood BD, DeCarlo JM. Observaciones ecológicas del vampiro Desmodus rotundus de Córdoba. Rev Mus Argentina Cienc Nat. 1961;6(4):131-60.

61. Fleming TH, Hooper ET, Wilson DE. Three Central American bat communities: structure, reproductive cycles, and movement patterns. Ecology. 1972;53(4):556-69.

62. Correa WM, Correa CNM. Doenças infecciosas dos mamíferos domésticos. 2nd ed. São Paulo, Brazil: Medsi; 1993.
63. Romijn PC, van der Poel WHM, van der Heide R, Cattaneo CAM, Silva RCF. Study of Lyssaviruses of bat origin as a source of rabies for other animal species in the State of Rio de Janeiro, Brazil. Am J Trop Med Hyg. 2003;69(1): 81-6.

64. Warrell MJ, Warrell DA. Rabies and other lyssavirus diseases. Lancet. 2004;363(9413): 959-69.

65. Schneider MC, Aron J, Santos-Burgoa C, Muñoz B, Ruiz-Velasco S, Uieda W. Potential force of infection of human rabies transmitted by common vampire bats in the Amazonian region of Brazil. Am J Trop Med Hyg. 1996; 55(6):680-4.

66. Secretaria de Vigilância em Saúde, Ministério da Saúde, Brasil. Vigilância em saúde no SUS: fortalecendo a capacidade de resposta aos velhos e novos desafios. Brasília: Ministério da Saúde; 2006. Available from: http://portal. saude.gov.br/portal/arquivos/pdf/livro nova_vigilancia_web.pdf. Accessed 10 June 2007.

67. Brandling-Bennett AD, Pinheiro F. Infectious diseases in Latin America and the Caribbean: are they really emerging and increasing? Emerg Infect Dis. 1996;2(1). Available from: http://www.cdc.gov/ncidod/eid/vol2no1/ eidpaho.htm.

68. Instituto Nacional de Pesquisas Espaciais, Ministério da Ciência e Tecnologia, Brasil. Projeto PRODES de monitoramento da floresta amazônica brasileira por satélite: estimativas anuais de desmatamento da Amazônia desde 1998. Available from: http://www.obt.inpe. br/prodes/prodes_1988_2005.htm. Accessed 10 June 2007.

69. Dantas TM, Fonteles LV. Avanço da fronteira agrícola na Amazônia. Available from: http:// bvs.panaftosa.org.br/textoc/avancos fronteira_agricola_amazonia.pdf. Accessed 31 October 2008.

70. Pan American Health Organization. Final report of the Expert Consultation on the Care of Persons Exposed to Rabies Transmitted by Vampire Bats; 1991 Apr 2-5; Washington, D.C. Washington, D.C.: PAHO; 1991. Available from: http://www.who.int/rabies/trs931 \%2006_05.pdf. Accessed 15 November 2007.

71. Fundação Nacional de Saúde, Ministério da Saúde, Brasil. Projeto morcego: ações de controle da raiva humana transmitida por morce- gos. Brasília: FUNASA; 1991. Available from: http://www.paho.org/Portuguese/AD/DPC/ $\mathrm{VP} /$ raiva-morcegos-anexo5.pdf. Accessed $18 \mathrm{Ap}-$ ril 2008.

72. Brasil. Secretaria de Vigilancia en Salud, Ministerio de la Salud, Brasil; Organización Panamericana de la Salud. Reunión técnica para evaluar la situación epidemiológica de rabia en Brasil con énfasis en la rabia transmitida por murciélagos; 2004 Jun 30-Jul 2; Brasilia, D.F. Available from: http://www.paho.org/ spanish/ad/dpc/vp/rabia-murcielagos.htm. Accessed 18 April 2008.

73. Organización Panamericana de la Salud. Consulta de Expertos de la OPS/OMS sobre Rabia Transmitida por Murciélagos Hematófagos en la Amazonia; 2006 Oct 10-11; Brasilia, D.F. Available from: http:/ /bvs.panaftosa.org.br/ textoc/XI_REDIPRA_Octubre2006_PRELIMI NAR. pdf. Accessed 18 April 2008.

74. Bol Epidemiol Lima. 2007;16(15). Available from: http:/ /www.dge.gob.pe/boletines/ 2007/15.pdf. Accessed 15 November 2007.

75. Secretaria de Vigilância em Saúde, Ministério da Saúde, Brasil. Raiva humana transmitida por morcegos no estado do Maranhão. Available from: http://portal.saude.gov.br/portal/ arquivos/pdf/Nota \% 20Tecnica \% 20\% 20 MA\%20surto\%20de\%20raiva\%20humana\% 2025\%2007\%2005.pdf. Accessed 12 June 2007.

76. Encyclopaedia Britannica's Advocacy for Animals. Interview with Rosalía Arteaga of the Amazon Cooperation Treaty Organization. Chicago: Encyclopaedia Britannica, Inc.; 2007. Available from: http://advocacy.britannica. com/blog/advocacy/2007/04/interviewrosalia-arteaga-of-the-amazon-cooperationtreaty-organization/. Accessed 9 April 2007.

77. Romijn PC, Paula Bruno LM, Paula Bruno AM, Santos Souza C, dos Santos HR, Silva Melo $C$, et al. Ações em saúde na vigilância e prevenção de enfermidades infecciosas no município de Miracema, RJ. Rev Bras Med Vet. Forthcoming 2008.

Manuscript received on 7 February 2008. Revised version accepted for publication on 4 August 2008.

RESUMEN La rabia en humanos transmitida por murciélagos vampiros aumentó en América Latina en 2005. Se notificaron varios brotes con un total de 55 personas enfermas, 41 de ellas en la región amazónica de Brasil. Perú y Bolivia acumularon el mayor número de casos notificados entre 1975 y 2006. En Perú se informaron brotes de más de 20 personas con rabia transmitida por murciélagos en las décadas de 1980 y 1990. En ese período se informó un número menor de casos en los brotes de Brasil. Al comparar los datos de estudios de campo realizados en Brasil en 2005 con los obtenidos en décadas anteriores se observaron situaciones similares en cuanto a los casos de mordidas por murciélagos a nivel local. En este estudio se presenta una revisión de la situación epidemiológica y, a partir de esa información, se discuten los posibles factores asociados con los brotes. Se revisan también las medidas de prevención y control ya recomendadas para hacer frente a este problema y se ofrecen algunas recomendaciones adicionales.

Palabras clave Rabia, epidemiología; rabia, transmisión; ecosistema amazónico; rabia, prevención y control; América Latina. 